\title{
Factors associated with parent-reported wheeze and cough in children living in an industrial area of Gauteng, South Africa
}

\author{
"Bukola G. Olutola ${ }^{1}$, Nico Claassen ${ }^{1}$, Janine Wichmann ${ }^{1}$, Kuku Voyi ${ }^{1}$ \\ ${ }^{1}$ School of Health Systems and Public Health, Faculty of Health Sciences, University of \\ Pretoria, South Africa
}

*Corresponding author: bukola.olutola @gmail.com

\begin{abstract}
We examined the factors associated with mother-reported wheeze and dry cough in children living in Tembisa, a residential and industrial community in South Africa. A cross-sectional sample of parents reported wheezing and dry cough in children (aged 1 to 26 months) by completing the standardized International Study of Asthma and Allergies in Childhood questionnaire with additional questions concerning tobacco use, income, living conditions and mothers' educational level. Data were analysed using chi-square, univariate, and multiple logistic regressions. Of the 493 children who participated, 81 (16.4\%) had wheeze ever and $186(37.7 \%)$ had dry cough ever. We observed that children had a higher probability of wheezing if mothers had lived in the area for longer periods ( $a \mathrm{OR}: 1.05 ; 95 \% \mathrm{CI}: 1.01-1.08)$. Children who had trucks passing on their streets frequently were more likely to have had dry cough ever compared to those with no trucks passing on their streets $(a \mathrm{OR} ; 3.88$ : 95\% CI: 2.29-6.57). In Tembisa, dry cough in a child was associated with the frequency of trucks passing in front of the child's home. Children were also more likely have wheeze if their mothers had been living in the community for longer times.
\end{abstract}

Keywords: Wheeze, dry cough, children, Industry, trucks, South Africa 


\section{Introduction}

Around the world, more than $80 \%$ of people living in urban areas, where air pollution is monitored, are exposed to air pollution levels that exceed the guideline values of the World Health Organization (WHO 2016). In South Africa, measuring and improving air quality is considered a priority (Venter et al. 2012) due to the effect of air pollution on human health. The potential public health consequences of poor air quality led to the promulgation of the South African National Environmental Management: Air Quality Act in 2005, introducing air quality management (AQM) as a control strategy (Naiker et al. 2012).

In South Africa, poor land use planning has resulted in heavy industrial development taking place close to densely populated residential areas (DEA 2012). These industrial areas experience emissions from factories and high traffic volumes. These industries and traffic sources usually release pollutants which reduce the ambient air quality. Many of these residential areas are usually poor, and occupants are often reliant on fossil fuels for cooking, heating, and lighting. People living in these communities are known to suffer adverse health outcomes due to exposure to high levels of pollution emitted from the burning of fossil fuels (Scorgie et al. 2004), which may be further be exacerbated by pollution from nearby industries.

Air pollution is a significant cause of morbidity and of diminished health-related quality of life (Martinez et al. 2018). Adults and children living in areas with high levels of air pollution are more likely to have respiratory diseases and symptoms (Zhang et al. 2015). Children are particularly vulnerable to respiratory disease caused by air pollution because their lungs and immune system are not completely developed, and they inhale a lot more air than adults in proportion to their weight (El-Gamal and El-Sayed 2011; Schwartz 2004). These factors make the first years of life particularly critical for the development of asthma and allergies (Landau 2006). Studies have also shown that factors operating in the first year of life are critical in determining the onset and persistence of wheezing in preschool children (Fogaca et al. 2014; Oddy et al. 2002; Bercedo-Sanz et al. 2015; Young et al. 2000). Wheeze and persistent cough in infants are severe respiratory symptoms that can be triggered by respiratory infections due to viruses or due to a variety of environmental exposures (Fogaca et al. 2014; Morgan et al. 2005; Belanger et al. 2003). 
Many children who wheeze early in life have only a few episodes and outgrow their symptoms by school age (Piipo-Savolainen and Korppi 2008). Despite this, children with transient early wheeze are predisposed to an asthma diagnosis later in childhood (Savenije et al. 2011). In the industrial areas of Tembisa, South Africa where this study was carried out, a previous study found an association between air pollution and prevalence of wheeze, cough and allergies in adolescents (Shirinde et al. 2014). The concentrations of air pollutants such as particulate matter in this community are increasing. With these increases in air pollution and population density (Ekurhuleni) and industrialisation, we surveyed the prevalence of wheeze and dry cough in infants between one and twenty-six-month-old as reported by their mothers.

\section{Methods}

\section{Data and study population}

This cross-sectional study, assessed mother reported wheeze and dry cough in young children. The survey was conducted from February to December 2016 in the Olifantsfontein and Clayville industrial areas of Tembisa in the Ekurhuleni Metropolitan Municipality (EMM) of Gauteng Province, South Africa. Tembisa is the second largest township in the province, with both formal and informal housing, mainly inhabited by Black/Africans (Ekhuruleni 2005). A variety of industries cause pollution, including heavy manufacturing industries, a coal fired power station, brickworks, sewage works, light industrial processes, quarry facilities, waste sites, motor vehicles, farming and domestic fuel combustion (Ekhuruleni 2005). Residential areas around Olifantsfontein and Clayville industrial areas include Clayville formal settlement and Tswelapele informal settlement.

\section{Sample size}

We recruited 550 mothers and their very young children (1-26 months) who attended Olifantsfontein clinic for immunization- the main clinic serving the residents of the two industrial areas. We recruited mothers at their homes if they did not attend the clinic. Only 493 mothers and their children (89.6\% response rate) participated in the study and analyses due to incomplete data. We used modified interviewer-administered ISAAC phases I and III (for 6 to 7-year-olds) and the American Thoracic Society and National Heart and Lung Institute-Division of Lung Disease Respiratory questionnaires (ATS-DLD 78) for the babies and the mothers respectively. The Ethics Committee of the University of Pretoria, Pretoria, South Africa (Protocol number 309/2014) approved the study. 


\section{Air pollution in Tembisa}

The Ekurhuleni Metropolitan Municipality operates a mobile ambient air quality monitoring station which has been operational since 2012. The particulate matter levels for PM10 in Olifantsfontein, Clayville and Tswelopele are usually above the National Ambient Air Quality Standard (NAAQS) of $50 \mu \mathrm{g} / \mathrm{m}^{3}$ annual mean and $120 \mu \mathrm{g} / \mathrm{m}^{3}$ 24-hour mean. Sulphur dioxide (SO2) levels occasionally exceed the NAAQS mainly due to the large volume of heavy duty trucks that operate in the area. The rest of the pollutants measured at the station (nitrogen oxides, benzene and ozone) are below the NAAQS (DEA 2015).

\section{Measures}

\section{Health Outcomes}

Mothers either answered yes or no to the following questions:

- Has your child ever had wheezing or whistling in the chest?

- Has your child ever had a dry cough, apart from a cough associated with a cold or chest infection?

Similar to a previous study, we explained wheeze to the mother as wheeze or whistling sounds, breathlessness or shortness of breath in their children (Cane and McKenzie 2001).

\section{Air pollution sources}

The questionnaire evaluated air pollution sources using the following items:

- Do the mother/father (or male guardian) smoke cigarettes (Yes/No)

- How many people smoke cigarettes in the house, including parents?

- What is the most frequently used source of energy at home for lighting, cooking, and heating? (electricity or non-electrical-gas, paraffin/ wood/coal)

- How often do trucks pass through the street where residents lived? (never/seldom/frequently through the day/almost every day)

\section{Confounders}

We assessed potential confounding variables including:

- Age of baby, gender (male/female), day-care attendance (Yes/No)

- How long the mother had lived in the residential area

- Primary materials used for the walls and the roof of the main dwelling (brick/mud/corrugated iron/wood/plastic/Tile) 
- Cat and dog currently in the home (Yes/No)

- Cat and dog in the home in the past six months (Yes/No)

- Use of paracetamol since the child was born (Never/ At least once in two weeks/At least a month)

- Use of antibiotics since the child was born (Yes/No)

- Ever wheeze in mothers (wheeze when the mother had a cold and wheeze occasionally apart from cold)

- Cough in mothers (Yes/No)-If the mother usually had cough on first going outdoors, excluding clearing of throat. Those who answered "Yes" were asked further questions such as:-

(a) Do you usually cough as much as 4 to 6 times a day, 4 or more days out of the week? (Yes/No)

(b) Do you usually cough at all on getting up, or first thing in the morning? (Yes/No) If "Yes" to any of the above,

(c ) Do you usually cough like this on most days for 5 consecutive months or more of the year? (Yes/No/Does not apply)

(d) For how many years have you had this cough?

- Mother's education (Primary school/ secondary/ tertiary education)

- Mother's employment status (Unemployed/employed).

\section{Data analysis}

Data were analysed using STATA version 12 . We carried out a descriptive analysis of the variables, and we tested differences between groups using chi-square tests. We used univariate regression $(\mathrm{p}<0.25)$ to identify explanatory variables. Following this, we used multivariable-adjusted logistic regression $(\mathrm{p}<0.05)$ to identify important associations between wheeze and dry cough, and explanatory variables in young children. Model simplification involved a backward deletion approach (Hosmer and Lemeshow 2000).

\section{Results}

The characteristics of the study participants are presented in Table 1 . The number of female children was slightly higher than their male counterparts. The prevalence of wheeze ever in children was $16.4 \%(n=81)$ while the prevalence of dry cough ever was $37.7 \%(n=186)$. Most mothers reported that trucks passed on their streets frequently every day (51.4\%), more than 
one-third reported that trucks few or no trucks passed their streets. The remaining mothers reported passage of truck everyday but infrequently (Table 1). The mean age and birth weight of the children was 11.3 months $(\mathrm{SD}=6.73)$ and $3.13 \mathrm{~kg}(\mathrm{SD}=0.53)$ respectively.

Table 1: Characteristics of the study population; mothers and children (1 - 26 months), living in Tembisa, South Africa (2016).

\begin{tabular}{|c|c|}
\hline Characteristic & $\%(\mathrm{~N}=493)$ \\
\hline \multicolumn{2}{|l|}{ Gender of child } \\
\hline Female & $50.1(239)$ \\
\hline Male & $49.9(238)$ \\
\hline \multicolumn{2}{|l|}{ Age of baby } \\
\hline $1-12$ months & $62.6(298)$ \\
\hline $13-24$ months & $37.4(178)$ \\
\hline \multicolumn{2}{|l|}{ Child attending day care } \\
\hline No & $87.2(422)$ \\
\hline Yes & $12.8(62)$ \\
\hline \multicolumn{2}{|c|}{ Trucks passing in front of house } \\
\hline No truck/seldom & $35.2(170)$ \\
\hline Frequently in a day & $51.4(248)$ \\
\hline Everyday & $13.5(65)$ \\
\hline \multicolumn{2}{|l|}{ Use of Panadol by baby } \\
\hline Never & $25.1(121)$ \\
\hline At least once in two weeks & $30.1(145)$ \\
\hline At least a month & $44.8(216)$ \\
\hline \multicolumn{2}{|l|}{ Child ever used antibiotics } \\
\hline No & $60.3(290)$ \\
\hline Yes & $39.7(191)$ \\
\hline \multicolumn{2}{|l|}{ Children ever had wheeze } \\
\hline No & $83.6(412)$ \\
\hline Yes & $16.4(81)$ \\
\hline \multicolumn{2}{|l|}{ Children ever had dry cough } \\
\hline No & $62.3(307)$ \\
\hline Yes & $37.7(186)$ \\
\hline \multicolumn{2}{|l|}{ Mothers ever had wheeze } \\
\hline No & $92.3(455)$ \\
\hline Yes & $7.7(35)$ \\
\hline \multicolumn{2}{|l|}{ Mothers ever had hay fever } \\
\hline No & 76.5 (377) \\
\hline Yes & $23.5(116)$ \\
\hline \multicolumn{2}{|l|}{ Mother's employment status } \\
\hline Unemployed & $80.8(390)$ \\
\hline Employed & $19.3(93)$ \\
\hline \multicolumn{2}{|l|}{ Cat currently in the home } \\
\hline No & $96.8(477)$ \\
\hline \multirow{2}{*}{\multicolumn{2}{|c|}{$\begin{array}{l}\text { Yes } \\
\text { Cat in the house in past } 6 \text { months }\end{array}$}} \\
\hline & \\
\hline No & $94.7(461)$ \\
\hline \multirow{2}{*}{\multicolumn{2}{|c|}{$\begin{array}{l}\text { Yes } \\
\text { Coughing in mothers }\end{array}$}} \\
\hline & \\
\hline No & $91.2(445)$ \\
\hline Yes & $8.8(43)$ \\
\hline \multicolumn{2}{|l|}{ Dog currently in the home } \\
\hline No & $92.9(455)$ \\
\hline Yes & $7.1(35)$ \\
\hline \multicolumn{2}{|c|}{ Dog in the house in past 6months } \\
\hline No & $86.6(420)$ \\
\hline Yes & $13.4(65)$ \\
\hline \multicolumn{2}{|l|}{ Heater in the house } \\
\hline No heater & $37.7(183)$ \\
\hline Non-electric heater & $45.6(221)$ \\
\hline Electric heater & $16.7(81)$ \\
\hline
\end{tabular}


A higher percentage of mothers whose children were attending day-care reported that their children ever had wheeze than those who did not attend (29.3\% vs. $14.9 \%$; $=0.018)$. The highest prevalence of wheeze ever was seen in children who lived in houses which had trucks passing frequently every day. There was no difference in the prevalence of wheeze ever in children living in houses which did not have trucks passing on their streets and those who had trucks passing everyday but not frequently. Children who had never used antibiotics had a lower prevalence of wheeze than children who had ever used $(11.2 \%$ vs. $23.0 \%$; $p=0.001)$ (Table 2). However, there was no difference in wheeze between children who had never taken paracetamol and those who had taken either at least once in two weeks or at least once a month.

Table 2: Prevalence and associated factors (univariate regression) of wheeze amongst children (1-26 months) living in Tembisa, Gauteng province, South Africa

\begin{tabular}{|c|c|c|c|}
\hline Characteristic & Prevalence \% (n) & $\begin{array}{l}\text { Crude odds ratio }(95 \% \\
\text { CI })\end{array}$ & p-value \\
\hline \multicolumn{4}{|l|}{ Age of child } \\
\hline $1-12$ months & $18.8(56)$ & 1.0 & \\
\hline $13-26$ months & $12.9(23)$ & $0.64(0.38-1.09)$ & 0.098 \\
\hline \multicolumn{4}{|l|}{ Child attending day care } \\
\hline No & $14.9(53)$ & 1.0 & \\
\hline Yes & $29.3(17)$ & $2.11(1.14-3.92)$ & 0.018 \\
\hline \multicolumn{4}{|l|}{ Child ever used antibiotics } \\
\hline No & $11.2(26)$ & 1.0 & \\
\hline Yes & $23.0(41)$ & $2.25(1.38-3.69)$ & 0.001 \\
\hline \multicolumn{4}{|l|}{ Trucks passing in front of house } \\
\hline No truck/seldom & $11.4(17)$ & 1.0 & \\
\hline Frequently per day & $21.6(44)$ & $1.89(1.08-3.32)$ & 0.025 \\
\hline Everyday & $15.3(9)$ & $1.53(0.69-3.40)$ & 0.298 \\
\hline \multicolumn{4}{|l|}{ Heater in the house } \\
\hline No heater & $23.3(34)$ & 1.0 & \\
\hline Electric heater & $11.3(22)$ & $0.50(0.29-0.85)$ & 0.010 \\
\hline Non-electric heater & $17.8(13)$ & $0.68(0.34-1.36)$ & 0.279 \\
\hline \multicolumn{4}{|l|}{ Cat in the house in past 6 months } \\
\hline No & $16.0(64)$ & 1.0 & \\
\hline Yes & $35.3(6)$ & $1.93(0.78-4.75)$ & 0.154 \\
\hline \multicolumn{4}{|l|}{ Dog currently in the house } \\
\hline No & $15.6(71)$ & 1.0 & \\
\hline Yes & $28.6(10)$ & $2.16(1.00-4.70)$ & 0.051 \\
\hline \multicolumn{4}{|l|}{ Mothers ever had wheeze } \\
\hline No & $14.6(57)$ & 1.0 & \\
\hline Yes & $40.6(13)$ & $3.38(1.66-6.86)$ & 0.001 \\
\hline \multicolumn{4}{|l|}{ Mothers ever had hay fever } \\
\hline No & $12.9(42)$ & 1.0 & \\
\hline Yes & $28.9(28)$ & $2.23(1.34-3.71)$ & 0.002 \\
\hline \multicolumn{4}{|l|}{ Mother's employment status } \\
\hline Unemployed & $14.2(48)$ & 1.0 & \\
\hline Employed & $29.3(22)$ & $1.88(1.09-3.25)$ & 0.024 \\
\hline $\begin{array}{l}\text { Number of years mother had spent in the } \\
\text { study community }\end{array}$ & & $1.03(1.00-1.06)$ & 0.021 \\
\hline
\end{tabular}


In the multivariate analysis, the longer a mother had lived in the community, the more likely the prevalence of wheeze in children (aOR: 1.04; 95\% Conf. Int: 1.01-1.08). Children who lived in a house with a dog were more likely to have wheeze compared to those who did not have a dog in the house ( $a$ OR: 3.31; 95\% Conf. Int: 1.30-8.44) (Table 3).

Table 3: Factors associated with wheeze amongst children (1-26 months) living in Tembisa, Gauteng province, South Africa

\begin{tabular}{lll}
\hline Characteristics & Adjusted odds ratio (95\% CI) & p-value \\
\hline $\begin{array}{l}\text { Number of years mother had spent in the } \\
\text { study community }\end{array}$ & $1.05(1.01-1.08)$ & 0.004 \\
$\begin{array}{l}\text { Mothers ever had wheeze } \\
\text { No }\end{array}$ & 1.0 & \\
Yes & $3.12(1.37-7.10)$ & 0.007 \\
$\begin{array}{l}\text { Age of child } \\
1-12 \text { months }\end{array}$ & 1.0 & \\
$\begin{array}{l}13-26 \text { months } \\
\text { Child ever used antibiotics }\end{array}$ & $0.54(0.30-0.96)$ & 0.036 \\
No & 1.0 & \\
$\begin{array}{l}\text { Yes } \\
\text { Dog currently in the house }\end{array}$ & $2.93(1.65-5.20)$ & $<0.001$ \\
No & & \\
Yes & 1.0 & 0.012 \\
\hline
\end{tabular}

Table 4 shows the prevalence of dry cough amongst the children along with the crude odds ratios of associated factors. Children who lived in houses where trucks did not pass their houses had the lowest prevalence of dry cough (21.8\%), followed by those who had trucks passing everyday but not frequently (35.4\%), followed by those who had trucks passing frequently in a day $(50.0 \%)$. Having a cat $(84.6 \%$ vs. $35.4 \%$; $\mathrm{p}<0.001)$ or a dog $(55.4 \%$ vs. $35.2 \% ; \mathrm{p}=0.002$ ) in the house in the past 6 months gave rise to a higher prevalence of dry cough than not having any pets. 
Table 4: Prevalence and associated factors (univariate regression) of dry cough amongst children (1-26 months) living in Tembisa, Gauteng province, South Africa

\begin{tabular}{|c|c|c|c|}
\hline Characteristic & Prevalence \% (n) & Crude odds ratio (95\% CI) & p-value \\
\hline \multicolumn{4}{|l|}{ Gender of child } \\
\hline Female & $36.6(85)$ & 1.0 & \\
\hline Male & $43.3(100)$ & $1.32(0.91-1.92)$ & 0.144 \\
\hline \multicolumn{4}{|l|}{ Age of baby } \\
\hline $1-12$ months & $44.6(127)$ & 1.0 & \\
\hline $13-24$ & $31.6(56)$ & $0.58(0.39-0.85)$ & 0.006 \\
\hline \multicolumn{4}{|c|}{ Trucks passing in front of house } \\
\hline No truck/seldom & $22.8(37)$ & 1.0 & \\
\hline Frequently in a day & $51.2(124)$ & $3.55(2.28-5.54)$ & $<0.001$ \\
\hline Everyday & $35.4(23)$ & $1.85(0.99-3.46)$ & 0.054 \\
\hline \multicolumn{4}{|l|}{ Use of Panadol by baby } \\
\hline Never & $27.8(32)$ & 1.0 & \\
\hline At least once in two weeks & $50.0(72)$ & $2.59(1.54-4.37)$ & $<0.001$ \\
\hline At least a month & $37.9(80)$ & $1.58(0.97-2.60)$ & 0.068 \\
\hline \multicolumn{4}{|l|}{ Mothers ever had wheeze } \\
\hline No & $36.1(158)$ & 1.0 & \\
\hline Yes & $73.7(28)$ & $4.96(2.35-10.48)$ & $<0.001$ \\
\hline \multicolumn{4}{|c|}{ Cat in the house in past 6 months } \\
\hline No & $36.5(163)$ & 1.0 & \\
\hline Yes & $84.6(22)$ & $9.58(3.25-28.29)$ & $<0.001$ \\
\hline \multicolumn{4}{|l|}{ Coughing in mothers } \\
\hline No & $36.0(155)$ & 1.0 & \\
\hline Yes & $69.8(30)$ & $4.11(2.08-8.11)$ & $<0.001$ \\
\hline \multicolumn{4}{|c|}{ Dog in the house in past 6months } \\
\hline No & $36.5(148)$ & 1.0 & \\
\hline Yes & $55.4(36)$ & $2.16(1.28-3.67)$ & 0.004 \\
\hline \multicolumn{4}{|l|}{ Heater in the house } \\
\hline No heater & $50.9(89)$ & 1.0 & \\
\hline Non-electric heater & $36.3(29)$ & $0.55(0.32-0.95)$ & 0.031 \\
\hline Electric heater & $30.1(65)$ & $0.42(0.28-0.63)$ & $<0.001$ \\
\hline
\end{tabular}

Unlike wheeze ever, dry cough ever was associated with gender and trucks passing in front of the house after controlling for confounding factors (Table 5). Male children were more likely to have dry cough compared to female children ( $a \mathrm{OR}: 1.02 ; 95 \%$ Conf. Interval: 1.02-2.50). Children whose mothers reported that trucks passed in front of their houses frequently in a day were more likely to have ever dry cough ( $a \mathrm{OR}: 3.88$; 95\% Conf. Interval: 2.29-6.57). (Table 5). 
Table 5: Factors associated with dry cough amongst children (1-26 months) living in Tembisa, Gauteng province, South Africa

\begin{tabular}{|c|c|c|}
\hline Characteristic & $\begin{array}{l}\text { Adjusted odds ratio (95\% } \\
\text { CI) }\end{array}$ & P-value \\
\hline \multicolumn{3}{|l|}{ Gender of the baby } \\
\hline Female & 1.0 & \\
\hline Male & $1.60(1.02-2.50)$ & 0.041 \\
\hline \multicolumn{3}{|l|}{ Age of the baby } \\
\hline $1-12$ months & 1.0 & \\
\hline 13-26 months & $0.51(0.32-0.83)$ & 0.006 \\
\hline \multicolumn{3}{|c|}{ Trucks passing in front of house } \\
\hline No truck/seldom & 1.0 & \\
\hline Frequently in a day & $3.88(2.29-6.57)$ & $<0.001$ \\
\hline Everyday & $1.49(0.73-3.03)$ & 0.269 \\
\hline \multicolumn{3}{|l|}{ Use of Panadol by baby } \\
\hline Never & 1.0 & \\
\hline At least once in two weeks & $3.45(1.85-6.43)$ & $<0.001$ \\
\hline At least a month & $3.43(1.87-6.30)$ & $<0.001$ \\
\hline \multicolumn{3}{|l|}{ Mothers ever had wheeze } \\
\hline No & 1.0 & \\
\hline Yes & $2.55(1.05-6.17)$ & 0.038 \\
\hline \multicolumn{3}{|c|}{ Cat in the house in past 6 months } \\
\hline No & 1.0 & \\
\hline Yes & $10.86(3.30-35.82)$ & $<0.001$ \\
\hline \multicolumn{3}{|l|}{ Heater in the house } \\
\hline No heater & 1.0 & \\
\hline Non-electric heater & $0.57(0.29-1.12)$ & 0.103 \\
\hline Electric heater & $0.43(0.26-0.70)$ & 0.001 \\
\hline \multicolumn{3}{|l|}{ Coughing in mothers } \\
\hline No & 1.0 & \\
\hline Yes & $2.85(1.26-6.44)$ & 0.012 \\
\hline
\end{tabular}

\section{Discussion}

We investigated factors associated with wheeze ever and dry cough ever in very young children living in an industrialized urban area in South Africa. We found that mothers reporting wheeze amongst their children were more likely to report using antibiotics in children, age of baby, the number of years the mothers had lived in the study community and the presence of a dog in the house. The factors associated with dry cough in children included trucks frequently passing in front of the house, use of paracetamol in children, the presence of a cat in the house in the past six months, cough in mothers, and gender of children.

The prevalence of 'ever wheezing' in the present study is lower than the previous estimations of "ever wheezing" in older school children in the same study setting in Tembisa (Shirinde et al. 2014). In this study, the prevalence of ever wheeze in young children was $16.4 \%$ while the prevalence among 13 and 14-year-old school children was 28.9\% (Shirinde et al. 2014).

There may be several reasons as to the low estimations in this study. The present study only included the youngest age category of one to twenty-six-month-old children which may be a 
problem for the identification of wheeze in children by their mothers. Because wheeze was based on parental report alone, children might have been labelled as having wheeze when they did not or labelled as not having wheeze when they had wheeze (Fernandes et al. 2011; Cave et al. 2014; Griffiths et al. 2018). Also, most wheeze in preschool children is associated with viral upper respiratory tract infections, which frequently recur in this age group (Brand et al. 2008; Gern 2010; Kieninger et al. 2012). Even wheezing in infancy has causal and risk factors which differ from the associated factors of wheezing illnesses in late preschool children (Brand et al. 2008). In 13 to 14-year-old children, wheeze was associated with passing trucks (Shirinde et al. 2014), whilst we did not find an association between passing trucks and wheeze in one to twenty-six- month-old children.

Wheezing may be an advance manifestation of respiratory symptoms and are not likely to be picked up or be as noticeable as dry cough. Ranzi et al. (2014) found no clear or consistent evidence of associations between exposure to traffic-related air pollution and wheezing symptoms. Cough, however, is a natural defence mechanism and dry cough at night may indicate allergy (Rancière et al. 2013). Dry cough frequently occurs in healthy children and can be increased by urban living and living in polluted cities (Mansour Ghanaie et al. 2013). Due to increases in urbanisation and industrialisation, the subsequent increases in air pollution and the respiratory health effects in children are of interest (Nel 2005; Naidoo et al. 2013). In Tembisa, we found that dry cough in small children was associated with trucks frequently passing in a day in front of houses where small children lived. Increases in the prevalence of cough in children have previously been associated with increases in exposure to traffic-related air pollution (Sucharew et al. 2010; Migliore et al. 2009). Traffic emissions, particularly from diesel vehicles, are a dominant source of $\mathrm{PM}_{2.5}, \mathrm{SO}_{2}$ and $\mathrm{NO}_{2}$ in the environment (Patel et al. 2009; Esplugues et al. 2011). Traffic emissions have been suggested to have substantial effects on the airways due to a high level of pulmonary deposition, and their ability to induce inflammation and oxidative stress (Schlesinger et al. 2006; Brandt et al. 2013).

In this study, ever wheeze in mothers was significantly associated with ever wheeze in children. Therefore, children whose mothers have a history of wheezing, should be targeted for early intervention to prevent wheezing illness (Seneviratne and Gunawardena 2018). Prenatal and direct exposure to air pollution may be associated with infant wheeze (Hehua et al.2017). In our study, mothers who had lived in the study area for longer were more likely to 
report that their children had wheeze. These mothers are more likely to have conceived and spent all their pregnancy months and their post-delivery months in the study area, implying both prenatal and direct exposure to air pollutants. Evidence indicates that prenatal exposure to air pollution is associated with the development of the respiratory and immune symptoms leading to respiratory morbidity and allergic responses during early life and beyond (Latzin et al. 2009; Mortimer et al. 2008; Proietti et al. 2012; Vieira 2015). Early exposure to air pollution is of greater significance than late life exposure due to the sensitivity of target organs such as the lungs and immune system during critical developmental periods (Mortimer et al. 2008).

We found that male children were more likely to have dry cough compared to female children, although there was no significant difference for wheeze ever. Jurca et al. (2017) found boys had a higher prevalence of cough until the age of about 13 years but the prevalence of cough increased in girls after that. In a male child, there is differential maturation in surfactant synthesis, airway size and airway resistance compared to female children (Carey et al. 2007; Ishak et al. 2014). Also, bronchial hyperresponsiveness in childhood is more common and more severe among boys than girls, although girls catch up during adolescence (Subbarao et al. 2009). These sex differences predispose male infants to childhood respiratory diseases.

Many children younger than two years wheeze if they have upper respiratory tract infections (Martinez et al. 1995; Kieninger et al. 2012) and these infections are often managed with antibiotics (Alrafiaah et al. 2017). Rusconi et al. (2011) showed that paracetamol and antibiotics were strongly associated with early wheezing. As wheeze and cough in the first years of life are often accompanied by fever, paracetamol is often used in children (Rakes et al. 1999; Jackson et al. 2008; van den Anker 2013). We found that wheezing was associated with using antibiotics, while dry cough was associated with using paracetamol. As the prevalence of dry cough is higher than wheeze, mothers are more likely to give paracetamol which is an over the counter medication, than antibiotics which has to be prescribed by a health professional. It is likely that this association is non-causative, because children are more likely to be given antibiotics or paracetamol if they are ill, and vice versa.

Wheezing and coughing in children are also associated with cat and dog allergens (Kerkhof et al. 2009). We found that presence of a cat in the house in the past 6 months was associated 
with dry cough in children. There was no association between the presence of a cat and wheeze in the study participants, but children living in houses with dogs were more likely to have wheeze. In the Netherlands, the incidence of wheeze and dry cough at night was higher in children with a dog from two years of age onwards (Kerkhof et al. 2009).

Other airborne allergens in the home could arise from non-electrical heating sources. We found that children from houses where there was a heater, especially an electric heater were less likely to have dry cough compared to children from homes with no heater or to homes with a non-electrical heater. Homes without electricity are more likely to use fossil fuels for cooking and heating, especially in winter. In the winter, houses are also poorly ventilated increasing the burden of exposure, especially for very young infants.

The findings of this study nevertheless need to be interpreted within the limitations of the study design. The study was cross-sectional, limiting inferences about causality as there is no temporal order of events, i.e., there may be reverse causality. The main weakness of our study is that it relies on mother-reported information for both symptoms and exposures which may lead to over or underestimation, and misclassification bias. Also, the mother-reported-nature of the health outcomes might have introduced reporting bias. Diagnosis of wheeze is based on parental report alone; therefore, children may be labelled as having wheeze when they do not. If possible, wheeze should be confirmed by a health professional, bearing in mind that not all healthcare workers are equally adept at estimating the severity of wheeze.

\section{Conclusion}

Wheeze and dry cough in children are important health outcomes. This study's findings found that dry cough in children was associated with trucks passing in front of a child's home. The study also showed that mothers who had lived for extended periods of time in the industrial community were more likely to have children who wheezed.

Conflict of Interest: The authors declare that they have no conflict of interest.

\section{Acknowledgements}

The authors express their gratitude to all the study participants and staff of Olifantsfontein Clinic. Special thanks are due to Sister Elsie for her support and Constance Makwetla for research assistance. 


\section{References}

Aguilera I, Pedersen M, Garcia-Esteban R, Ballester F, Basterrechea M, Esplugues A, Fernández-Somoano A, Lertxundi A, Tardón A, Sunyer J (2013) Early-life exposure to outdoor air pollution and respiratory health, ear infections, and eczema in infants from the INMA study. Environ Health Perspect 121:387-392

Alrafiaah AS, Alqarny MH, Alkubedan HY, AlQueflie S, Omair A (2017) Are the Saudi parents aware of antibiotic role in upper respiratory tract infections in children? Journal of Infection and Public Health 10:579-585

Belanger K, Beckett W, Triche E, Bracken MB, Holford T, Ren P, McSharry JE, Gold DR, Platts-Mills TA, Leaderer BP (2003) Symptoms of wheeze and persistent cough in the first year of life: associations with indoor allergens, air contaminants, and maternal history of asthma. Am J Epidemiol 158:195-202

Bercedo-Sanz A, Lastra-Martinez L, Pellegrini-Belinchon J, Vicente-Galindo E, LorenteToledano F, Garcia-Marcos L (2015) Wheezing and risk factors in the first year of life in Cantabria, Spain. The EISL study. Allergol Immunopathol (Madr) 43:543-552

Brand PLP, Baraldi E, Bisgaard H, Boner AL, Castro-Rodriguez JA, Custovic A de Blic J, de Jongste JC, Eber E, Everard ML, Frey U, Gappa M, Garcia-Marcos L, Grigg J, Lenney W, Le Souëf P, McKenzie S, Merkus PJ, Midulla F, Paton JY, Piacentini G, Pohunek P, Rossi GA, Seddon P, Silverman M, Sly PD, Stick S, Valiulis A, van Aalderen WM, Wildhaber JH, Wennergren G, Wilson N, Zivkovic Z, Bush A (2008). Definition, assessment and treatment of wheezing disorders in preschool children: an evidence-based approach. Eur Respir J 32:1096-1110

Brandt EB, Kovacic MB, Lee GB, Gibson AM, Acciani TH, Le Cras TD, Ryan PH, Budelsky AL, Khurana Hershey GK (2013) Diesel exhaust particle induction of IL-17A contributes to severe asthma. J Allergy ClinImmunol 132:1194-1204

Cane RS, McKenzie SA (2001). Parents' interpretations of children's respiratory symptoms on video. Arch Dis Child 84:31-34

Carey MA, Card JW, Voltz JW, Arbes SJ Jr, Germolec DR, Korach KS, Zeldin DC (2007) It's all about sex: gender, lung development and lung disease. Trends Endocrinol Metab 18:308-313 
Cave AJ, Lana LL (2014) Asthma in Preschool Children: A Review of the Diagnostic Challenges. J Am Board Fam Med 27:538-548

Clausen JL, Coates AL, Quanjer PH (1997) Measurement of lung volumes in humans: review and recommendations from an ATS/ERS workshop. Eur Respir J 10:1205-1206

Demissie K, Marcella SW, Breckenridge MB, Rhoads GG (1998) Maternal asthma and transient tachypnea of the newborn. Pediatrics 102:84-90

Department of Environmental Affairs -DEA (2015), Minister of Environmental Affairs Reply: Draft reply to Ms J Steenkamp (DA), 8 May 2015

https://www.environment.gov.za/sites/default/files/question1654_complaints_airquality_inar easofgauteng.pdf. Accessed 07 April 2017.

Department of Environmental Affairs -DEA (2012), South Africa Environment Outlook Chapter 5: Air Quality Draft 2 version 2.

http://soer.deat.gov.za/dm_documents/Chapter_5_Air_Quality_4kp8X.pdf. Accessed 07 April, 2017.

Ekhuruleni Metropolitan Municipality State of Energy report (2005). https://www.ekurhuleni.gov.za/471-state-of-energy-report-2005/file (Accessed 10 April, 2017)

Ekurhuleni (East Rand) Population. http://population.city/south-africa/ekurhuleni-east-rand/ El-Gamal YM, El-Sayed SS (2011) Wheezing in infancy. World Allergy Organ J:4(5):85 Esplugues A, Ballester F, Estarlich M, Llop S, Fuentes-Leonarte V, Mantilla E, Vioque J, Iñiguez C (2011) Outdoor, but not indoor nitrogen dioxide exposure is associated with persistent cough during the first year of life. Sci Total Environ 409:4667-4673

Fernandes RM, Robalo B, Calado C, Medeiros S, Saianda A, Figueira J, Rodrigues R, Bastardo C , Bandeira T (2011) The multiple meanings of "wheezing": a questionnaire survey in Portuguese for parents and health professionals. BMC Pediatrics 11:112

Fogaca HR, Marson FA, Toro AA, Sole D, Ribeiro JD (2014) Epidemiological aspects of and risk factors for wheezing in the first year of life. J Bras Pneumol 40:617-625

Gern JE (2010) The ABCs of Rhinoviruses, Wheezing, and Asthma. J Virol 84:7418-7426 
Griffiths LJ, Lyons RA, Bandyopadhyay A, Tingay KS, Walton S, Cortina-Borja M, Akbari A, Bedford H, Dezateux C (2018) Childhood asthma prevalence: cross-sectional record linkage study comparing parent-reported wheeze with general practitioner-recorded asthma diagnoses from primary care electronic health records in Wales. BMJ Open Resp Res 5:e00260. https://doi.org/10.1136/bmjresp-2017-000260

Hehua Z, Qing C, Shanyan G, Qijun W, Yuhong Z (2017) The impact of prenatal exposure to air pollution on childhood wheezing and asthma: A systematic review. Environ Res 159:519530. https://doi.org/10.1016/j.envres.2017.08.038

Hosmer DW, Lemeshow S (2000) Applied Logistic Regression New York: Wiley.

Ishak N, Sozo F, Harding R, De Matteo R (2014) Does lung development differ in male and female fetuses? Exp Lung Res 40:30-39

Jackson DJ, Gangnon RE, Evans MD, Roberg KA, Anderson EL, Pappas TE, Printz MC, Lee WM, Shult PA, Reisdorf E, Carlson-Dakes KT, Salazar LP, DaSilva DF, Tisler CJ, Gern JE, Jurca M, Ramette A, Dogaru CM, Goutaki M, Spycher BD, Latzin P, Gaillard EA, Kuehni CE (2017) Prevalence of cough throughout childhood: A cohort study. PLoS ONE 12(5): e0177485. https://doi.org/ 10.1371/journal.pone.0177485

Lemanske RF Jr (2008) Wheezing rhinovirus illnesses in early life predict asthma development in high risk children. Am J Respir Crit Care Med 178:667-672

Kerkhof M, Wijga AH, Brunekreef B, Smit HA, De Jongste JC, Aalberse RC, Hoekstra MO, Gerritsen J, Postma DS (2009) Effects of pets on asthma development up to 8 years of age: the PIAMA study. Allergy 64(8): 1202-1208

Kieninger E, Fuchs O, Latzin P, Frey U, Regamey N (2012) Rhinovirus infections in infancy and early childhood. Eur Respir J 52. https://doi.org/10.1183/09031936.00203511

Landau LI (2006) Paediatric basis of adult lung disease. Paediatr Respir Rev 7:S251-S254

Latzin P, Roosli M, Huss A, Kuehni CE, Frey U (2009) Air pollution during pregnancy and lung function in newborns: a birth cohort study. Eur Respir J 33:594-603

Levy ML, Godfrey S, Irving CS, Sheikh A, Hanekom W, Bush A, Lachman P (2004) Wheeze Detection: Recordings vs. Assessment of Physician and Parent. J Asthma 41:845853 
Mansour Ghanaie MR, Fahimzad SA, Karimi A (2013) Management of Chronic Cough in Children. Arch Pediatr Infect Dis 1:136-143

Martinez FD, Wright AL, Taussig LM, Holberg CJ, Halonen M, Morgan WJ (1995) Asthma and wheezing in the first six years of life. N Engl J Med 332:133-138

Martinez GS, Spadaro JV, Chapizanis D, Kendrovski V, Kochubovski M, Mudu P (2018) Health Impacts and Economic Costs of Air Pollution in the Metropolitan Area of Skopje. Int. J. Environ. Res. Public Health 15, 626. https://doi.org/10.3390/ijerph15040626

Masoli M, Fabian D, Holt S, Beasle R (2004). The global burden of asthma: executive summary of the GINA dissemination committee report. Allergy 59:469-78

Migliore E, Berti G, Galassi C, Pearce N, Forastiere F, Calabrese R, Armenio L, Biggeri A, Bisanti L, Bugiani M, Cadum E, Chellini E, Dell'orco V, Giannella G, Sestini P, Corbo G, Pistelli R, Viegi G, Ciccone G; SIDRIA-2 Collaborative Group (2009) Respiratory symptoms in children living near busy roads and their relationship to vehicular traffic: results of an Italian multicentre study (SIDRIA2). Environ Health 8:27. https://doi.org/10.1186/1476069X-8-27

Morgan WJ, Stern DA, Sherrill DL, Guerra S, Holberg CJ, Guilbert TW, Taussig LM, Wright AL, Martinez FD (2005) Outcome of asthma and wheezing in the first 6 years of life: follow-up through adolescence. Am J Respir Crit Care Med 172:1253-1258

Mortimer K, Neugebauer R, Lurmann F, Alcorn S, Balmes J, Tager I (2008) Air Pollution and Pulmonary Function in Asthmatic Children: Effects of Prenatal and Lifetime Exposures. Epidemiology 19:550-557

Naidoo RN, Robins TG, Batterman S, Mentz G, Jack C (2013) Ambient pollution and respiratory outcomes among schoolchildren in Durban, South Africa. South African Journal of Child Health 7:127-134

Naiker Y, Diab RD, Zunckel M, Hayes ET (2012) Introduction of local air quality management in South Africa: overview and challenges. Environ Sci Policy 17:62-71 Nel A (2005) Air pollution-related illness: effects of particles. Science 308: 804-806 Nyquist AC, Gonzales R, Steiner JF, Sande MA (1998). Antibiotic prescribing for children with colds, upper respiratory tract infections, and bronchitis. JAMA 279:875-877 
Oddy WH, de Klerk NH, Sly PD, Holt PG (2002) The effects of respiratory infections, atopy, and breastfeeding on childhood asthma. Eur Respir J 19:899-905

Patel MM, Hoepner L, Garfinkel R, Chillrud S, Reyes A, Quinn JW, Perera F, Miller R L (2009) Ambient metals, elemental carbon, and wheeze and cough in New York City children through 24 months of age. Am J Respir Crit Care Med 180:1107-1113

Piipo-Savolainen E, Korppi M (2008) Wheezy babies-wheezy adults? Review on long-term outcome until adulthood after early childhood wheezing. Acta Paediatr 97:5-11

Proietti E, Roosli M, Frey U, Latzin P (2012) Air Pollution During Pregnancy and Neonatal Outcome: A Review. Journal of Aerosol Medicine and Pulmonary Drug delivery 25:1-15. https://doi.org/10.1089/jamp.2011.093

Rakes GP, Arruda E, Ingram JM, Hoover GE, Zambrano JC, Hayden FG, Platts-Mills TA, Heymann PW (1999) Rhinovirus and respiratory syncytial virus in wheezing children requiring emergency care. IgE and eosinophil analyses. Am J Respir Crit Care Med 159:785790

Ranzi A1, Porta D, Badaloni C, Cesaroni G, Lauriola P, Davoli M, Forastiere F (2014) Exposure to air pollution and respiratory symptoms during the first 7 years of life in an Italian birth cohort. Environ Med 71:430-436. https://doi.org/10.1136/oemed-2013-101867

Rancière F, Nikasinovic L, Momas I (2013). Dry night cough as a marker of allergy in preschool children: the PARIS birth cohort. Pediatric Allergy and Immunology: Official Publication of the European Society of Pediatric Allergy and Immunology 24(2): 131137. https://doi.org/10.1111/pai.12045

Reijonen TM, Kotaniemi-Syrjanen A, Korhonen K,Korppi M (2000) Predictors of asthma three years after hospital admission for wheezing in infancy. Pediatrics 106: 1406-1412

Rusconi F, Gagliardi L, Galassi C, Forastiere F, Brunetti L, La Grutta S, Piffer S, Talassi F; SIDRIA-2 Collaborative Group (2011) Paracetamol and antibiotics in childhood and subsequent development of wheezing/asthma: association or causation? Int J Epidemiol 40:662-667 https://doi.org/10.1093/ije/dyq263

Savenije OE, Granell R, Caudri D, Koppelman GH, Smit HA, Wijga A, de Jongste JC, Brunekreef B, Sterne JA, Postma DS, Henderson J, Kerkhof M (2011) Comparison of 
childhood wheezing phenotypes in 2 birth cohorts: ALSPAC and PIAMA. J Allergy Clin Immunol 127:1505-1512

Schlesinger RB, Kunzli N, Hidy GM, Gotschi T, Jerrett M (2006) The health relevance of ambient particulate matter characteristics: coherence of toxicological and epidemiological inferences. Inhal Toxicol 18:95-125

Schwartz J (2004) Air pollution and children's health. Pediatrics 113:1037-1043

Scorgie Y, Annegarn H, Burger L (2004). Study to examine the potential socioeconomic impact of measures to reduce air pollution from combustion, Fund For Research into Industrial Development Growth and Equity (FRIDGE). Trade and Industry Chamber, Johannesburg.

Seneviratne R, Gunawardena NS (2018). Prevalence and associated factors of wheezing illnesses of children aged three to five years living in under-served settlements of the Colombo Municipal Council in Sri Lanka: a cross-sectional study. BMC Public Health 18:127. https://doi.org/10.1186/s12889-018-5043-3

Shirinde J, Wichmann J, Voyi K (2014) Association between wheeze and selected air pollution sources in an air pollution priority area in South Africa: a cross-sectional study. Environ Health 6;13:32. https://doi.org/10.1186/1476-069X-13-32

Sporik R, Holgate ST, Cogswell JJ (1991). The natural history of asthma in childhood: a birth cohort study. Arch Dis Child 66:1050-1053

Stocks J, Quanjer PH (1995) Reference values for residual volume, functional residual capacity and total lung capacity. ATS Workshop on Lung Volume Measurements. Official statement of the European Respiratory Society. Eur Respir J 8:492-506

Subbarao P, Mandhane PJ, Sears MR (2009) Asthma: epidemiology, etiology and risk factors. CMAJ 181: E181-190. pmid:19752106

Sucharew H, Ryan PH, Bernstein D, Succop P, Khurana Hershey GK, Lockey J Villareal M, Reponen T, Grinshpun S, LeMasters G (2010) Exposure to traffic exhaust and night cough during early childhood: the CCAAPS birth cohort. Pediatr Allergy Immunol 21:253-259 Venter AD, Vakkari V, Beukes JP, van Zyl PG, Laakso H, Mabaso D, Tiitta P, Josipovic M, Kulmala M, Jacobus J. Pienaar JJ, Laakso L (2012) An air quality assessment in the 
industrialised western Bushveld Igneous Complex, South Africa. S Afr J Sci 108(9/10). http:// dx.doi.org/10.4102/sajs. v108i9/10.1059

WHO Global Urban Ambient Air Pollution Database (update 2016)

http://www.who.int/phe/health_topics/outdoorair/databases/cities/en/ (Accessed 07 April, 2017).

Van den Anker JN (2013) Optimising the management of fever and pain in children. Int J Clin Pract, 67 (Suppl. 178): 26-32. https://doi.org/10.1111/ijcp.12056

Vieira SE (2015) The health burden of pollution: the impact of prenatal exposure to air pollutants. Int J Chron Obstruct Pulmon Dis 10:1111-

1121.https://doi.org/10.2147/COPD.S40214

Young S, Arnott J, O'Keeffe PT, Le Souef PN, Landau LI (2000) The association between early life lung function and wheezing during the first 2 yrs of life. Eur Respir J 15:151-157

Zhang Q, Qiu M, Lai K, Zhong M (2015) Cough and environmental air pollution. Pulm. Pharmacol. Ther. 35:132-136 